\title{
The Type III Secretion System of Biocontrol Pseudomonas fluorescens KD Targets the Phytopathogenic Chromista Pythium ultimum and Promotes Cucumber Protection
}

\author{
Fabio Rezzonico, ${ }^{1}$ Christian Binder, ${ }^{1}$ Geneviève Défago, ${ }^{1}$ and Yvan Moënne-Loccoz ${ }^{2}$ \\ ${ }^{1}$ Phytopathology Group, Institute of Plant Sciences, Swiss Federal Institute of Technology (ETH), Universitätstrasse 2, \\ CH-8092 Zürich, Switzerland; '²UR CNRS 5557 Ecologie Microbienne, Université Claude Bernard (Lyon 1), 43 bd du 11 \\ Novembre 1918, F-69622 Villeurbanne cedex, France
}

Submitted 20 December 2004. Accepted 9 May 2005.

\begin{abstract}
The type III secretion system (TTSS) is used by Proteobacteria for pathogenic or symbiotic interaction with plant and animal hosts. Recently, TTSS genes thought to originate from the phytopathogen Pseudomonas syringae were evidenced in Pseudomonas fluorescens KD, which protects cucumber from the oomycete Pythium ultimum (kingdom Chromista/Stramenopila). However, it is not known whether the TTSS contributes to plant protection by the bacterium and, if so, whether it targets the plant or the phytopathogen. Inactivation of TTSS gene hrcV following the insertion of an omega cassette strongly reduced the biocontrol activity of the pseudomonad against $P$. ultimum on cucumber when compared with the wild type, but had no effect on its root-colonization ability. Analysis of a plasmid-based transcriptional hrpJ'inaZ reporter fusion revealed that expression in strain $\mathrm{KD}$ of the operon containing $h r c V$ was strongly stimulated in vitro and in situ by the oomycete and not by the plant. In vitro, both strain $K D$ and its $h r c V$ mutant reduced the activity level of the pectinase polygalacturonase (a key pathogenicity factor) from $P$. ultimum, but the reduction was much stronger with the wild type. Together, these results show that the target range of bacterial TTSS is not restricted to plants and animals but also can include members of Chromista/Stramenopila, and suggest that virulence genes acquired horizontally from phytopathogenic bacteria were functionally recycled in biocontrol saprophytic Pseudomonas spp., resulting in enhanced plant protection by the latter.
\end{abstract}

The type III secretion system (TTSS), which is widely distributed among proteobacterial pathogens of plants (belonging to the genera Pseudomonas, Erwinia, Xanthomonas, and Ralstonia), animals, and humans (Hueck 1998), functions as a molecular syringe for the introduction of virulence factors directly into eukaryotic host cells. The introduced factors then are able to subvert host cell functions in a way that is beneficial to the invading bacteria. In plant pathogens, type III secretion is essential for the induction of disease in susceptible host plants (Alfano and Collmer 1997).

Corresponding author: Y. Moënne-Loccoz; Telephone: +33 4724313 49; Fax: +33 4724312 23; E-mail: moenne@ biomserv.univ-lyon1.fr
The existence of functional TTSS also has been demonstrated in nonpathogenic bacteria, i.e., the plant symbiont Rhizobium, which has the ability to invade the root of legumes and fix atmospheric nitrogen within root nodules (Freiberg et al. 1997; Gottfert et al. 2001; Meinhardt et al. 1993), as well as plant-associated saprophytic pseudomonads (Mulya et al. 1996; Preston et al. 2001). Functionality of hrp genes was shown by in vivo expression technology (IVET) for root-colonizing Pseudomonas fluorescens SBW25 (Rainey 1999), although its $h r p$ cluster lacks part of $h r c V$ and $h r c N$ (Preston et al. 2001). Many of these plant-associated saprophytic pseudomonads are plant growth-promoting rhizobacteria (PGPR) and benefit the plant via biological control of soilborne pathogens (Preston et al. 2001; Rezzonico et al. 2004). TTSS genes seem to be widespread among plant-beneficial pseudomonads based on polymerase chain reaction (PCR) sequencing and hybridization of TTSS genes $h r c N$ (Rezzonico et al. 2004) and hrcRST (Mazurier et al. 2004). This raises the question of the contribution of TTSS genes to beneficial prokaryote-eukaryote interactions taking place between root-associated pseudomonads and the plant, especially in the case of biocontrol interactions.

In Pseudomonas spp., the phylogenetic relationship derived from $r r s$, which codes for the 16S rRNA, matches the species phylogeny (Anzai et al. 2000). Phylogenetic comparison of $r r s$ and the ATPase-encoding TTSS gene $h r c N$ among biocontrol and phytopathogenic pseudomonads showed that $h r c N$ is ancient in most lineages and has evolved in parallel with $r r s$, with $h r c N$ alleles of most biocontrol pseudomonads differing clearly from those found in phytopathogenic counterparts (Rezzonico et al. 2004). In contrast, the $h r c N$ allele found in the biocontrol strain Pseudomonas fluorescens KD clustered with alleles from phytopathogenic bacteria in the $h r c N$ trees, pointing to an evolutionarily recent acquisition of the gene by horizontal gene transfer from phytopathogenic $P$. syringae (Rezzonico et al. 2004). However, despite exhibiting a phytopathogenic attribute, Pseudomonas fluorescens KD does not behave as a phytopathogen, based on its inability to elicit the hypersensitive response and to cause any disease symptoms on tobacco or cucumber (Rezzonico et al. 2004). This means that strain KD acts as neither a noncompatible pathogen nor a compatible one, whereas the established phytopathogen $P$. syringae exhibits both properties. In contrast, strain KD shows outstanding biocontrol effects, noticeably against damping-off disease of cucumber caused by Pythium ultimum (Sharifi-Tehrani et al. 1998). This led us to 
hypothesize that TTSS in Pseudomonas fluorescens strain KD targets the phytopathogen rather than the plant and, thus, may contribute to plant protection by the biocontrol bacterium.

The aim of this work was to investigate the significance of TTSS with respect to biocontrol interactions in Pseudomonas fluorescens KD. Inactivation of TTSS gene $h r c V$ was implemented and the resulting mutant compared with the wild type based on i) biocontrol performance against $P$. ultimum on cucumber and ii) direct effects on growth and virulence potential of the pathogen. In addition, a transcriptional inaZ fusion to the TTSS promoter controlling the expression of the $h r p J$ operon (containing $h r c V$ ) was constructed, resulting in plasmid pADJ6, and the plasmid used to assess induction of TTSS genes in response to the presence of the plant, the pathogen, or both. The results obtained indicate that i) functional TTSS genes play a key role in the biocontrol activity of $\mathrm{KD}$, ii) their expression is induced by the presence of the pathogenic oomycete $P$. ultimum, and iii) their contribution to biocontrol targets the phytopathogen itself and not the plant host.

\section{RESULTS}

Construction and in vitro assessment

of an $\mathbf{h r c V}$-negative mutant of Pseudomonas fluorescens KD.

For construction of an $h r c V$ mutant of Pseudomonas fluorescens KD, a 1,718-bp PstI fragment (including the final 219 bp of $h r p J$ and the first 1,503 bp of $h r c V$ ) obtained from strain KD was interrupted at a $S m a$ I site (i.e., position 915 of $h r c V$ ) with an $\Omega$ cassette carrying a kanamycin-resistance gene (Fig. 1 ). This fragment was cloned into the suicide vector pME3087 (Voisard et al. 1994) and the resulting plasmid (named pCBW) mobilized into strain KD. Correct insertion of the $\Omega$ cassette within $h r c V$ was verified for kanamycin-resistant tetracycline-sensitive Pseudomonas colonies, both by PCR (using $\Omega$ primers) and Southern blot on PstI-digested genomic DNA. In one colony, chromosomal integration of the cassette by double homologous recombination was further confirmed by sequencing (performed by Microsynth $\mathrm{GmbH}$, Balgach, Switzerland), and it was used as an $h r c V^{-}$mutant of KD. Plasmid extractions using the Wizard Plus SV Minipreps DNA Purification System confirmed the absence of pCBW (and of any other plasmid) in the $h r c V^{-}$mutant.

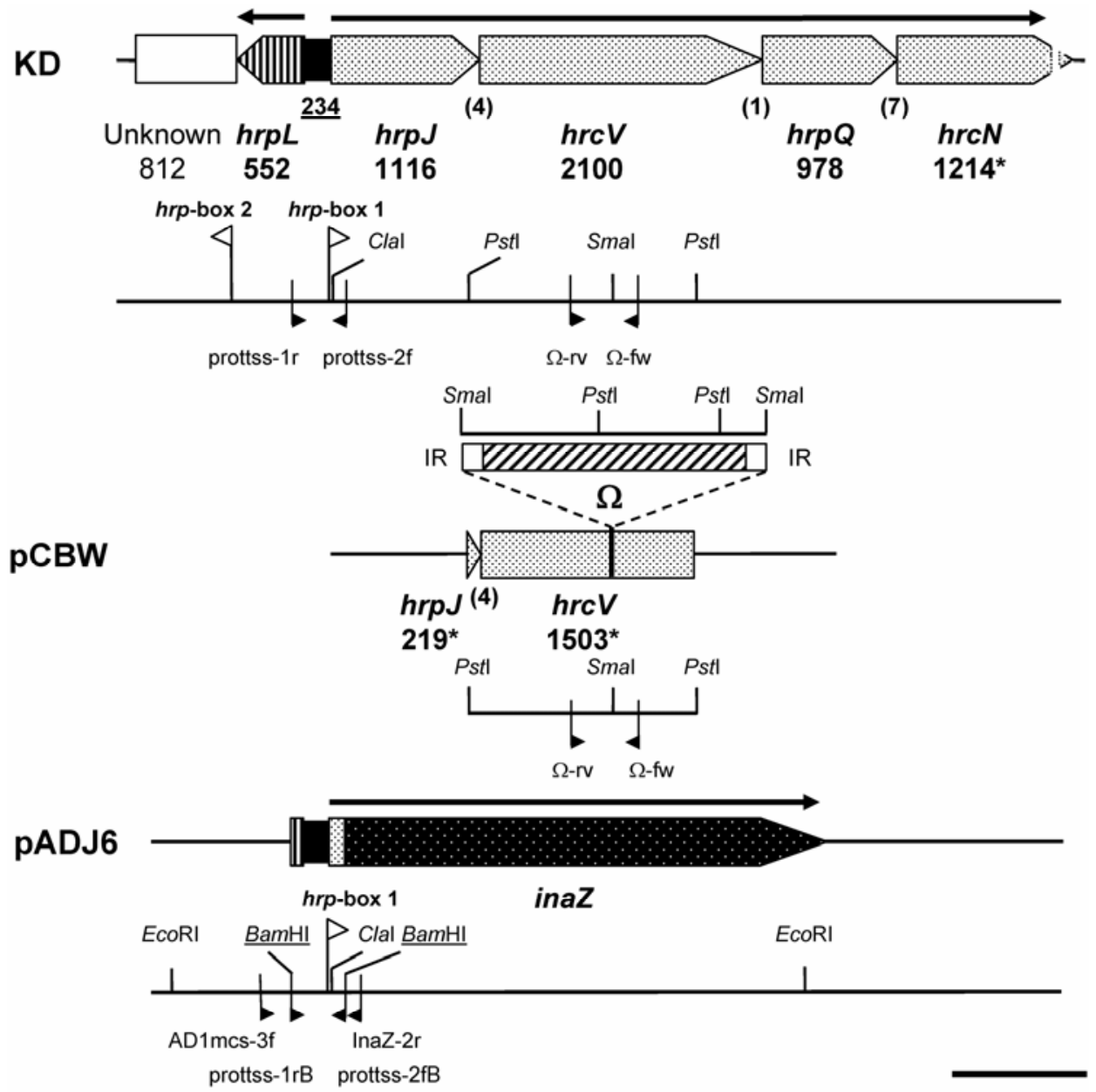

$1 \mathrm{~kb}$

Fig. 1. Genetic organization of type III secretion system genes found in biocontrol strain Pseudomonas fluorescens KD (accession number AY463491; Rezzonico et al. 2004) (upper panel) and construction of suicide plasmid pCBW (to generate an $h r c V$ mutant) (middle panel) and the reporter construct pADJ6 (lower panel). The length of each gene (bp) is shown below its name, with partially sequenced or truncated genes indicated by an asterisk $(*)$. The length of noncoding, intergenic gaps is underlined and the number of bases shared by overlapping genes is indicated between parentheses. The horizontal arrows above the genes $\rightarrow$ ) represent putative operons and the direction in which they are transcribed. The position of relevant restriction sites is indicated and, in the case of pADJ6, their names are underlined when corresponding to a site inserted by polymerase chain reaction (PCR). Black triangles ( $)$ represent the position and orientation of PCR primers used for cloning and verification of the constructs. The white triangles $(D)$ indicate the position and orientation of the $h r p$ transcription boxes $h r p$-box 1 (GGAACCCGATGGTGGGTTTGCGCCACGCA) and $h r p$-box 2 (GGAACCTCTTTCGCCTCTGGC TCCACTCA), whose $h r p$ box consensus (Xiao and Hutcheson 1994) contains the motif (shown in bold) GGAACC-N $16^{-C C A C-N_{2}-A}$ (Fouts et al. 2002). IR $=$ inverted repeats flanking the $\Omega$ cassette. 
The growth rate of the $h r c V^{-}$mutant did not differ from that of the wild-type KD in Luria Bertani (LB; Sambrook et al. 1989), King's B (King et al. 1954), potato dextrose broth, or minimal medium (Huynh et al. 1989). Both bacteria also showed the same pattern of utilization of 95 different compounds as sole $\mathrm{C}$ source in Biolog GN microplates (BIOLOG Inc., Hayward, CA). In addition, the capacity to produce biocontrol secondary metabolites such as hydrogen cyanide and pyoverdine was unaffected by the mutation. These findings point to the absence of pleiotropic effects associated with $h r c V$ inactivation in strain KD.

\section{Effect of hrcV inactivation in Pseudomonas fluorescens KD on biocontrol of damping-off of cucumber.}

In the absence of the pathogen $P$. ultimum, inoculation of Pseudomonas fluorescens $\mathrm{KD}$ or its $h r c V$-deficient mutant to
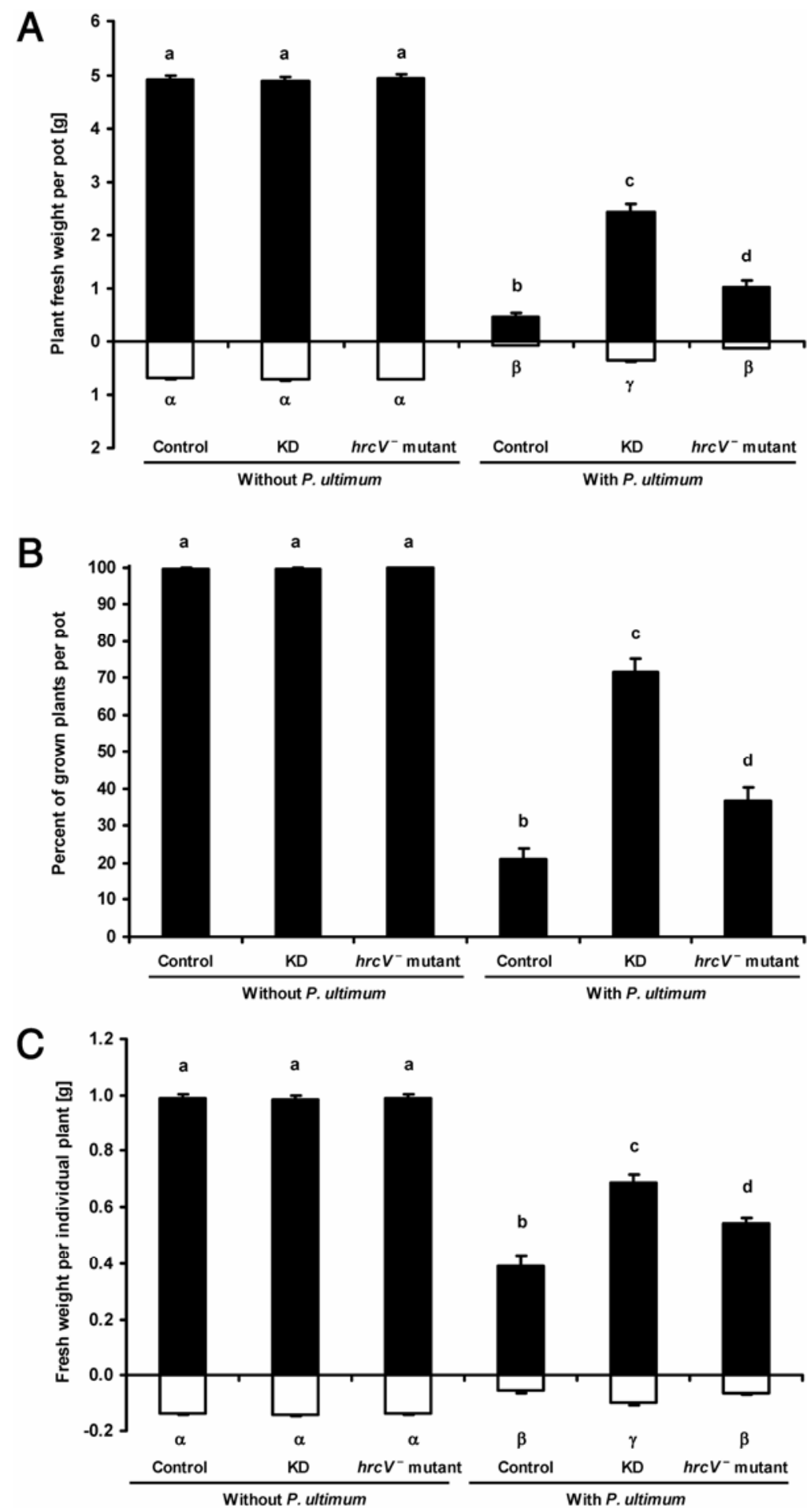

Fig. 2. A, Biocontrol of Pythium ultimum-mediated damping-off of cucumber by Pseudomonas fluorescens KD and its hrcV mutant in nonsterile potting mix at 7 days. A, Total fresh weight of shoots (in black, upper part of the figure) and roots (in white, lower part of the figure) recorded per pot. B, Percentage of plants alive. C, Fresh weight of shoots (in black, upper part of the figure) and roots (in white, lower part of the figure) of individual plants. Means and standard errors (error bars) were derived from nine replicates. Two-way analysis of variance (Pseudomonas treatment $\times$ Pythium treatment) was performed, and data with the same Latin or Greek letter are not significantly different (Tukey's honestly significant difference test at $P<0.05$ ). 
nonsterile potting mix had no effect on health (data not shown), fresh weight, or emergence (Fig. 2) of cucumber plants at 7 days under growth chamber conditions. Addition of the pathogen $P$. ultimum alone lowered seedling emergence to only $21 \%$ (Fig. 2B) and reduced significantly the average biomass of surviving plants from 1.13 to $0.45 \mathrm{~g}$ per plant (sum of roots + shoots) (Fig. 2C), which overall resulted in a $91 \%$ loss in the total plant biomass per pot (Fig. 2A). In the presence of $P$. ultimum, the biocontrol strain $\mathrm{KD}$ increased plant emergence from 21 to $72 \%$ and the biomass of individual plants from 0.45 to $0.79 \mathrm{~g}$ per plant (i.e., $+76 \%$ ). Therefore, total plant biomass per pot was increased more than four times when compared with the nonprotected treatment. The $h r c V$-deficient mutant also had statistically significant positive effects on plant emergence (from 21 to $37 \%$ ) and the biomass of surviving plants (from 0.45 to $0.61 \mathrm{~g}$ of roots + shoots per plant), but these effects were much lower than those of the wild type, especially when considering plant emergence. Consequently, total plant biomass per pot was only $40 \%$ of that in the KD treatment.

To determine whether the disruption of the $h r c V$ gene had any influence on the ability of $\mathrm{KD}$ to survive in potting mix and to colonize cucumber roots, CFU of the bacteria in the biocontrol assay were determined. Results indicate that both inoculants survived well in potting mix and colonized the rhizosphere and roots at high cell numbers $\left(>10^{7} \mathrm{CFU} \mathrm{\textrm {g } ^ { - 1 }}\right.$ of rhizosphere soil or root) (Fig. 3) by day 7. Importantly, there was no statistically-significant difference in population level between strain $\mathrm{KD}$ and its $h r c V^{-}$mutant, regardless of i) the compartment studied and ii) whether the pathogen was present. We infer that, at least during the observation period, the $h r c V$ mutation did not reduce the ecological fitness of the inoculant.

\section{Construction}

of an $\boldsymbol{h r p J}$ '-inaZ promoter transcriptional fusion.

An $h r p J$ '-inaZ promoter transcriptional fusion was constructed in the pPROBE'gfp[tagless] (Miller et al. 2000) derivative pAD1. A 405-bp PCR amplicon containing the promoter region of the $h r p J$ operon of strain $\mathrm{KD}$ was ligated upstream of inaZ within pAD1, yielding pADJ6 (Fig. 1). The correct orientation of a single insert in the plasmid was confirmed by restriction analysis and PCR. Plasmid pADJ6 was purified from Escherichia coli and transformed into $\mathrm{CaCl}_{2-}$ competent KD cells.

Under in vitro conditions, retention of the reporter plasmid pADJ6 in strain KD was $96.0 \pm 1.3 \%$ after 20 generations and $90.2 \pm 2.4 \%$ after 35 generations in serial LB cultures (i.e., subculturing done every $12 \mathrm{~h}$ over 4 days) without selection for plasmid maintenance. The reporter gene was expressed at a very low basal level, i.e., $-8.01( \pm 0.47) \log _{10}$ (ice nuclei $\bullet$ cell $\left.^{-1}\right)$, when strain KD/pADJ6 was grown overnight in LB (i.e., under the conditions used to prepare the inoculum for microcosm experiments). Thus, the levels of activity that were measured in this work reflect actual gene activity during the course of the experiments rather than the residual activity of inoculant cells. No inaZ activity was found in strain KD or KD containing the empty vector $\mathrm{pAD} 1$.

\section{In vitro activity of the hrp promoter in the presence of $P$. ultimum and cucumber seedlings.}

The effect of autoclaved 2-day-old cucumber seedlings and $P$. ultimum on ice nucleation activity of strain KD/pADJ6 was assessed during $27 \mathrm{~h}$ in liquid LB culture. Growth of strain $\mathrm{KD} / \mathrm{pADJ} 6$ was the same in all treatments (Fig. 4A). Ice nucleation activity increased in parallel to cell numbers in the KD/pADJ6 control (Fig. 4B). The presence of autoclaved cucumber seedlings had no effect on ice nucleation activity (Fig. 4B), and the same finding was made when using surface-disinfected seedlings (in the presence of kanamycin at $10 \mu \mathrm{g} \mathrm{ml}^{-1}$ to avoid contaminations) (data not shown). In contrast, the activity of the hrp promoter was significantly higher (up to one log unit) from $19 \mathrm{~h}$ on (i.e., from the end of the exponential growth phase) in the presence of $P$. ultimum.

\section{In situ activity of the hrp promoter}

in the cucumber- $P$. ultimum pathosystem.

Ice nucleation activity was assessed in situ at 7 days in a biocontrol experiment in which strain KD/pADJ6 was used

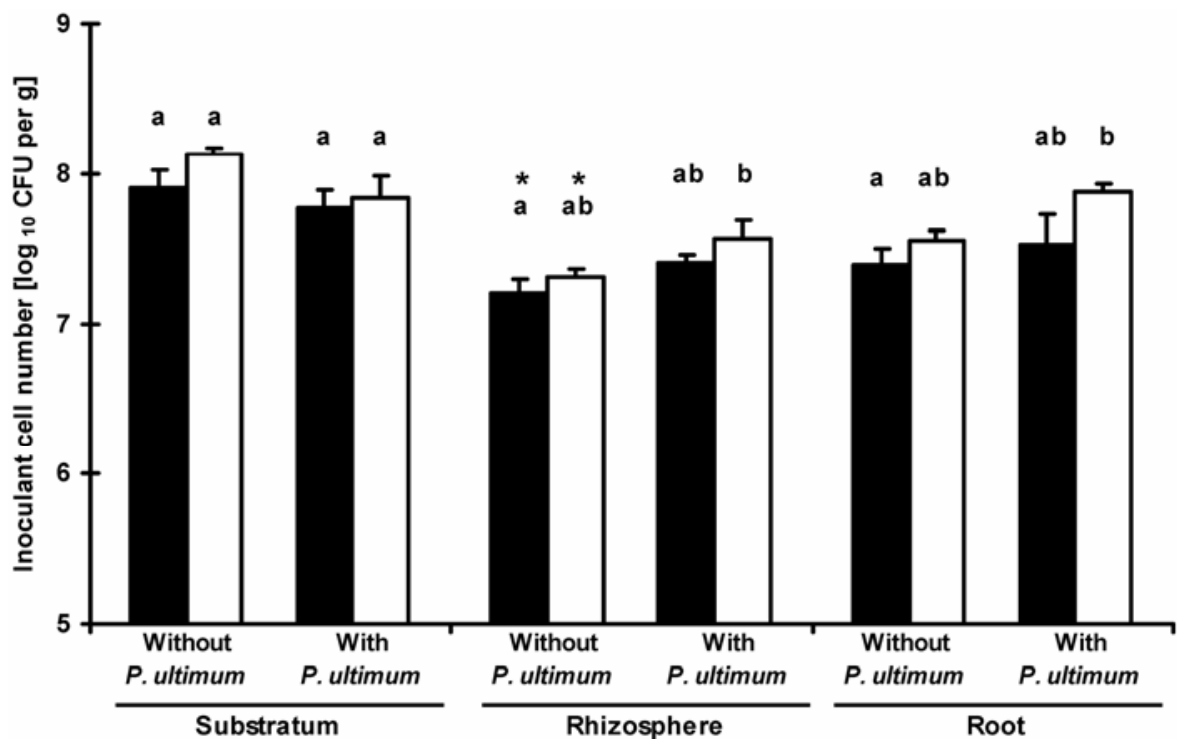

Fig. 3. Survival of Pseudomonas fluorescens KD (black bars) and its hrcV mutant (white bars) at 7 days in the substratum, rhizosphere, and roots of cucumber grown in nonsterile potting mix. CFU are expressed per gram of potting mix (for substratum and rhizosphere) or root (for the root compartment). Bacteria were inoculated at $10^{7} \mathrm{CFU}$ per gram of potting mix. Means and standard deviations (error bars) were derived from four replicates. Within each compartment, two-way analysis of variance (ANOVA) (Pseudomonas treatment $\times$ Pythium treatment) was performed, and data with the same letter are not significantly different (Tukey's honestly significant difference test at $P<0.05$ ). In both the presence or absence of added pathogen, the data for substratum and rhizosphere also were compared together (because both are expressed per gram of potting mix) for each corresponding treatment and statistically significant differences (ANOVA at $P<0.05$ ) between the two are indicated by an asterisk $(*)$ on the bars of the latter compartment. 
(Fig. 5). In this experiment, levels of plant emergence and biomass in the KD/pADJ6 treatment were the same as the ones achieved with strain KD in the original biocontrol experiment, and no indigenous ice nucleation activity was detected in the control treatments without added bacteria (data not shown). The reporter plasmid pADJ6 was maintained between 96.7 and $98.0 \%$, based on analysis of inoculant cells reisolated at 7 days and that grew on kanamycin-amended agar, regardless of i) the microbial compartment (potting mix substratum, rhizosphere, or root) and ii) whether P. ultimum was added. A basic hrpJ' inaZ activity level was recorded after residence of KD/pADJ6 cells for 7 days in nonsterile potting mix substratum without added pathogen. By comparison with the potting mix substratum, a modest increase in inaZ activity of strain KD/pADJ6 was found in the rhizosphere (2.6-fold) and on roots (6-fold) in the absence of the pathogen. However, in the presence of the latter, the increase was 17 -fold in the potting mix substratum,
133 -fold in the rhizosphere, and 184-fold on the roots. In each of the three compartments, the activity of the hrp promoter was significantly higher when P. ultimum was added.

Effect of $\boldsymbol{h r c} \boldsymbol{V}$ inactivation on $P$. ultimum pectinase activity.

The production by phytopathogens of extracellular lytic enzymes (e.g., pectinase, which contributes to the breakdown of pectins in plant cell walls) is important for pathogenesis (Walton 1994). Here, we used the activity level of the pectinase polygalacturonase as an indicator of the virulence potential of P. ultimum when assessing the effect of Pseudomonas fluorescens KD and its $h r c V$-deficient mutant on the phytopathogen. The confrontation experiment was carried out in liquid media and aliquots were sampled periodically to assess pectinase activity. No pectinase activity could be detected in the absence of $P$. ultimum (data not shown). When P. ultimum was incubated alone in LB, pectinase production was first detected
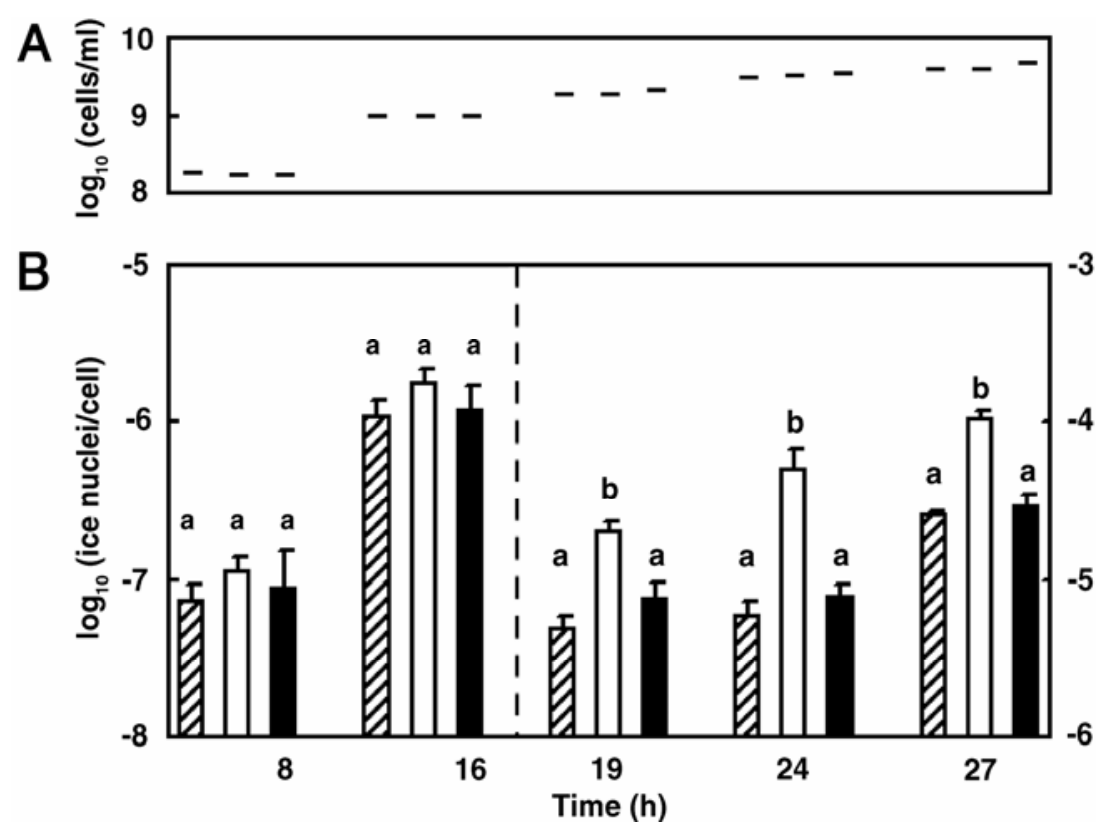

Fig. 4. Effect of Pythium ultimum (black bars) or autoclaved cucumber seedlings (white bars) on A, growth and $\mathbf{B}$, ice nucleation activity of the hrpJ'-inaZ fusion of Pseudomonas fluorescens KD/pADJ6 in Luria Bertani medium. Hatched bars represent the control (i.e., strain KD/pADJ6 alone). Values are the means of four replicates and error bars in B represent standard deviations. At each sampling time, treatments with the same letter are not significantly different (analysis of variance and Tukey's honestly significant difference test at $P<0.05$ ).

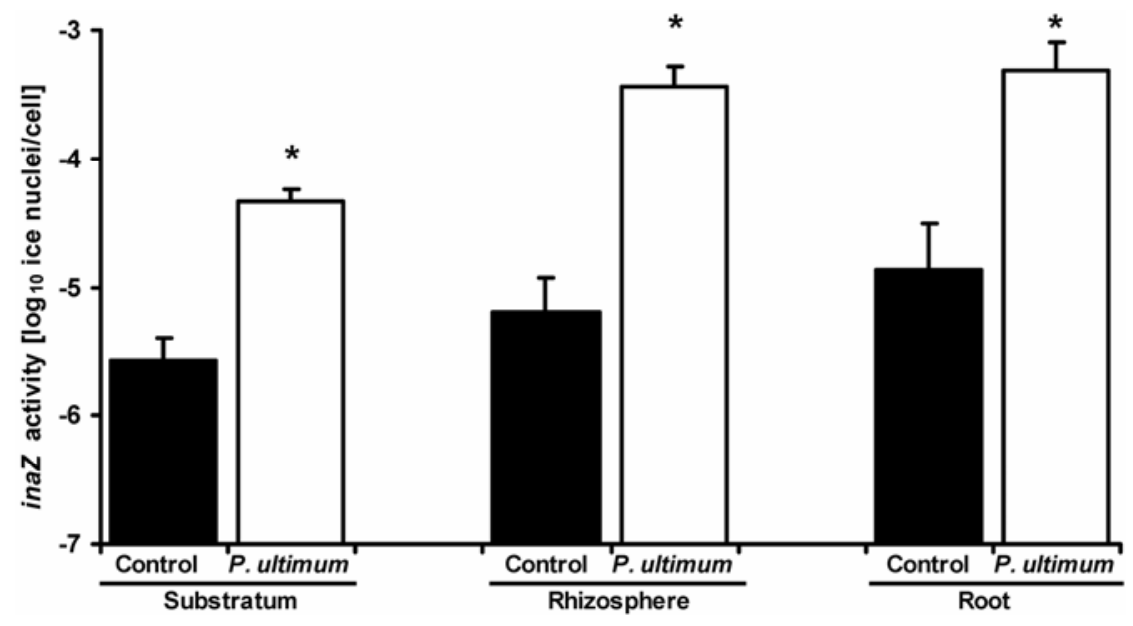

Fig. 5. Activity of the $h r p J^{\prime}$-inaZ fusion of Pseudomonas fluorescens KD/pADJ6 at 7 days in the substratum, rhizosphere, and roots of cucumber grown in nonsterile potting mix inoculated (white bars) or not (black bars) with Pythium ultimum. inaZ activity is expressed as the logarithm of the number of ice nuclei per cell of strain KD/pADJ6. Values are the means of four replicates and error bars represent standard deviations. Statistically-significant differences resulting from $P$. ultimum inoculation (analysis of variance at $P<0.05$ ) are marked by an asterisk (*). 
at 40 h (Fig. 6A). When P. ultimum was challenged with Pseudomonas fluorescens $\mathrm{KD}$, pectinase production was delayed and levels were statistically lower. In contrast, the $h r c V^{-}$mutant did not delay pectinase production in $P$. ultimum. In addition, pectinase levels were statistically higher with the $h r c V^{-}$ mutant compared with KD. The same findings were made when macerated cucumber seedlings were added (Fig. 6B) or when Czapek-Malt was used instead of LB (Fig. 6C and D), except in Czapek-Malt supplemented with macerated cucumber seedlings where, at $26 \mathrm{~h}$, pectinase production already was detected in the control but not in the two bacterial treatments (data not shown). In contrast, no significant effect on pectinase activity was found when supplementing the P. ultimum culture with cell-free LB culture supernatants of strain $\mathrm{KD}$ (in a $1: 1$ ratio), meaning that the pseudomonad requires direct physical contact with the pathogen.

\section{DISCUSSION}

The unexpected occurrence of TTSS genes in antagonistic biocontrol bacteria has been documented in recent years (Preston et al. 2001; Mazurier et al. 2004; Rezzonico et al. 2004). For instance, Preston and associates (2001) have shown the presence in Pseudomonas fluorescens SBW25 of a $20-\mathrm{kb}$ gene cluster (named $r s p$, for rhizosphere-expressed secretion) that resembles the type III ( $h r p$ ) gene cluster of plant-pathogenic $P$. syringae. For one of these genes, expression was demonstrated in the rhizosphere, but a knock-out mutant was not available to assess the ecological significance of TTSS in this bacterium. Such a mutant was obtained in the current work with the insertion of an $\Omega$ cassette containing a kanamycinresistance determinant (2,237 bp long) into the $h r c V$ gene of Pseudomonas fluorescens $\mathrm{KD}$, because mutational inactivation of $h r c V$ abolishes type III secretion in bacteria (Casper-Lindley et al. 2002; Holeva et al. 2004).

Most TTSS genes found so far in KD (Rezzonico et al. 2004) are organized as in the plant pathogens Erwinia amylovora Ea321 (Bogdanove et al. 1998), P. syringae pv. tomato DC3000 (Fouts et al. 2003), and P. syringae pv. syringae 61 (Alfano et al. 2000), with $h r p J, h r c V, h r p O$, and $h r c N$ located in the same operon controlled by a unique hrp-box sequence (Fouts et al. 2002), which is recognized by the alternate sigma factor HrpL (Xiao and Hutcheson 1994). Therefore, in addition to the inactivation of $h r c V$, the presence of the $\Omega$ cassette in $h r c V$ i) causes a frameshift (polar mutation) and ii) ensures via transcription and translation termination sequences that the nine TTSS genes located downstream in the hrpJ operon are not functional anymore (Prentki and Krisch 1984). However, the $h r c V$ mutant did not differ from the wild-type strain KD when grown alone under in vitro conditions, based on comparison of growth rates, utilization of 95 compounds as sole $\mathrm{C}$ source, and the ability to produce the biocontrol compounds hydrogen cyanide and pyoverdine.

Despite not producing the key biocontrol compound 2,4diacetylphloroglucinol often associated with plant protection in pseudomonads, Pseudomonas fluorescens $\mathrm{KD}$ is an effective biocontrol agent (Sharifi-Tehrani et al. 1998), which was confirmed here. The results of our study indicate that inactivation of $\mathrm{hrcV}$ strongly reduced the biocontrol capacity of Pseudomonas fluorescens $\mathrm{KD}$ against damping-off in the $P$. ulti-
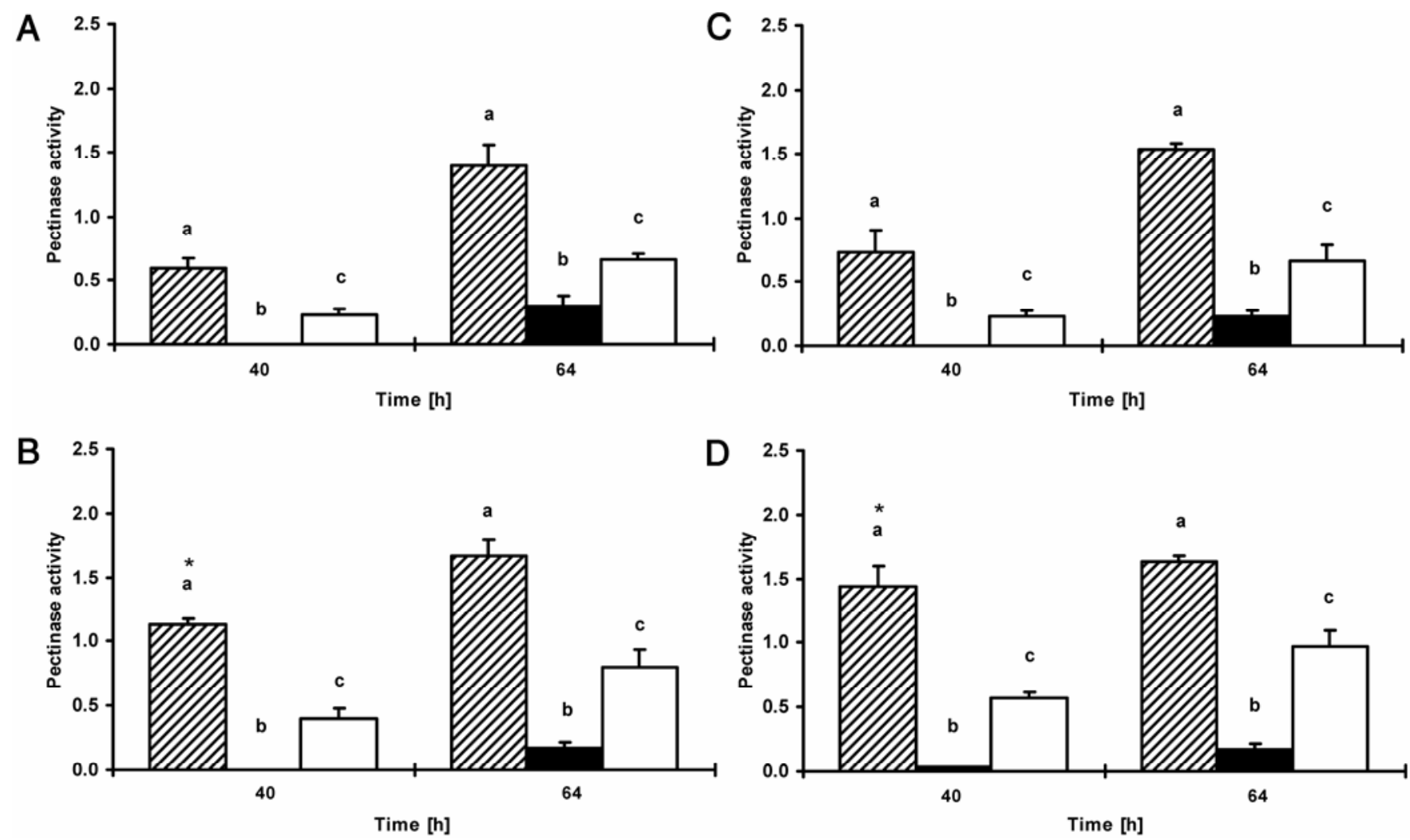

Fig. 6. Effect of Pseudomonas fluorescens KD (black bars) and its hrcV mutant (white bars) on the pectinase activity of Pythium ultimum in A and B, Luria Bertani or $\mathbf{C}$ and D, Czapek-Malt medium. Samples in B and D were incubated in presence of macerated cucumber seedlings. Hatched bars represent controls without bacteria. The activity was assessed in a cup-plate assay by measuring the diameter of the polygalacturonic acid-free zone around a 0.6-cm well in which a $200-\mu \mathrm{l}$ sample was incubated for 2 days at $24^{\circ} \mathrm{C}$. Values are the means of three replicates and error bars represent standard deviation of the means. At each sampling, two-way analysis of variance (ANOVA) (Pseudomonas treatment $\times$ medium) was performed. Within each of the four graphs, treatments with the same letter are not significantly different (Tukey's honestly significant difference tests at $P<0.05$ ). For each treatment, statistically significant differences (ANOVA at $P<0.05$ ) due to the presence of macerated cucumber seedlings are indicated by an asterisk $(*)$. 
mum-cucumber pathosystem. This effect was not due to a lower ecological fitness of the $h r c V$ mutant, because the latter persisted in potting mix and colonized plant roots to the same extent as the wild-type strain KD did, regardless of whether the pathogen was present or not. To our knowledge, this is the first report of TTSS being involved in the biocontrol activity of a plant-beneficial bacterium. In addition, when taking into account the hypothesis of an evolutionarily recent horizontal transfer of TTSS genes from the phytopathogen Pseudomonas syringae to the nonpathogen Pseudomonas fluorescens KD (Rezzonico et al. 2004), this points to the hypothesis that phytovirulence genes were functionally recycled, once acquired, as components of the plant-protection arsenal of the biocontrol bacterium.

Interestingly, the $h r c V$-deficient mutant displayed weak but statistically significant plant-protection effects, in accordance with the fact that, like the wild-type (Sharifi-Therani et al. 1998), it produces pyoverdine and hydrogen cyanide, the latter being of particular importance for Pythium biocontrol (Ellis et al. 2000; Ramette et al. 2003; Valverde et al. 2003). Horizontal acquisition of symbiotic or pathogenic ability (Blanc-Potard and Lafay 2003; Dale et al. 2001; Manulis and Barash 2003; Ochman and Moran 2001; Sullivan et al. 1995) is well established. In the case of Pseudomonas fluorescens KD, we hypothesize that horizontal gene transfer has turned a weak biocontrol agent into an effective one.

Expression of TTSS genes is strongly induced when pathogenic (Aldon et al. 2000; Rosqvist et al. 1994; Watarai et al. 1995) or symbiotic (Dale et al. 2002) bacteria interact with their host. Here, we used plasmid pADJ6, which carries an hrpJ'-inaZ promoter transcriptional fusion, and ice nucleation assays to assess the activity of Pseudomonas fluorescens KD's hrpJ operon in the cucumber-P. ultimum pathosystem. In a previous study, reporter technology showed that the TTSS gene $r s c C$ was expressed when the biocontrol strain Pseudomonas fluorescens SBW25 colonizes the rhizosphere (Preston et al. 2001). In the current work, however, the effect of the plant on $h r p J^{\prime}$-inaZ activity level was small, as indicated by the comparison of potting mix, rhizosphere, and root samples in the absence of added P. ultimum (Fig. 5). This observation is consistent with the fact that strain KD is neither pathogenic to cucumber nor causes a noncompatible (hypersensitive) response in the host plant. In contrast with this finding, the addition of $P$. ultimum to nonsterile potting mix produced a strong increase in $h r p J$ promoter activity in Pseudomonas fluorescens KD/pADJ6, regardless of whether potting mix, rhizosphere, or root samples were considered. This leads to the concept that the TTSS of Pseudomonas fluorescens KD targets the pathogen $P$. ultimum during bacterial interaction with the plant, rather than the plant host. Indeed, cucumber seedlings had no effect on hrpJ'-inaZ activity when strain KD/pADJ6 was grown in vitro, whereas the pathogen did (Fig. 4).

The finding that $P$. ultimum is the true target of the TTSS of strain KD is further supported by the fact that the mutation in $h r c V$ reduced the ability of the bacterium to inhibit the production of the pectinase polygalacturonase by P. ultimum. Indeed, production of extracellular lytic enzymes such as pectinases (which contribute to the breakdown of pectins in plant cell walls) is important for disease induction by phytopathogens (Agrios 1997). Because pectinase is a key virulence factor, it is no surprise that strain KD resulted in a diminished ability of $P$. ultimum to infect emerging plants, allowing them to grow beyond the stage where they can develop endogenous resistance against this pathogen following lignification and suberification of plant cell walls (Agrios 1997). This effect appears to be specific, because strain KD had no effect on colony growth of $P$. ultimum on plates (data not shown). This is the first time that TTSS was demonstrated to mediate deleterious effects against an eukaryote that is neither an animal nor a plant. Indeed, $P$. ultimum (family Pythiaceae, class Oomycetes, phylum Oomycota) belongs to the Chromista/Stramenopila kingdom (CABI database IndexFungorum), which also includes Prymnesiophyta, Sagenistans, diatoms, silicoflagellates, and golden, brown, and yellow-green algae (Campbell et al. 1999; Cavalier-Smith 1997; Cavalier-Smith et al. 1994). Horizontal transfer of virulence genes from bacterial pathogens of plants and animals may confer recipient bacteria the ability to cause disease to a plant or an animal, respectively (Blanc-Potard and Lafay 2003; Dale et al. 2001; Manulis and Barash 2003). Here, however, a TTSS thought to originate from a phytopathogen (Rezzonico et al. 2004) targeted a Chromista that was pathogenic to the plant, and it is now favoring the plant when the latter was faced with the pathogen.

\section{MATERIALS AND METHODS}

\section{Microorganisms and culture conditions.}

Escherichia coli strains were grown routinely in LB medium at $37^{\circ} \mathrm{C}$ and Pseudomonas strains on King's B agar or in LB broth at $27^{\circ} \mathrm{C}$. Strain KD/pADJ6 was grown in the presence of kanamycin $\left(50 \mu \mathrm{g} \mathrm{ml}^{-1}\right)$. P. ultimum 67-1 (obtained from Allelix Agriculture, Mississauga, Ontario, Canada) was cultured on $1.5 \%$ malt agar plates (Difco Laboratories, Detroit) at $20^{\circ} \mathrm{C}$ for 7 days. Antibiotics were used at the following concentrations unless otherwise mentioned: ampicillin at $100 \mu \mathrm{g} \mathrm{ml}^{-1}$, tetracycline at $25 \mu \mathrm{g} \mathrm{ml}^{-1}$, and kanamycin at $25 \mu \mathrm{g} \mathrm{ml}^{-1}$.

\section{Construction, verification, and}

in vitro assessment of an $\boldsymbol{h r c V ^ { - }}$ mutant of KD.

A 1,718-bp PstI fragment encompassing the final $219 \mathrm{bp}$ of $h r p J$ and the first 1,503 bp of $h r c V$ (4-bp overlap between both genes) was cloned into plasmid pUK21 (Vieira and Messing 1991), as described previously (Rezzonico et al. 2004), yielding plasmid pCBTypeIII. pCBTypeIII was digested with HindIII and $\mathrm{XbaI}$ and the resulting fragment cloned into pBluescript II KS (Stratagene, Cedar Creek, TX, U.S.A.). The intermediate product was cut at position 915 of $h r c V$ with $S m a$ I, blunted, and ligated with an $\Omega$ cassette, resulting in plasmid pCBB12. The $\Omega$ cassette, which carries a kanamycin resistance gene, was derived from plasmid pHP45 (Fellay et al. 1987) by EcoRI digestion and blunting prior to the ligation. pCBB12 was cut with XhoI, blunted, then digested with $X b a I$. The excised fragment carrying TTSS genes was cloned into the suicide plasmid pME3087 (Voisard et al. 1994), previously cut with HindIII, blunted, and digested with $X b a \mathrm{I}$. This pME3087 derivative was named pCBW (Fig. 1) and was mobilized by biparental mating from $E$. coli DH5 $\alpha$ containing the helper plasmid pME497 to E. coli HB101. In a second biparental mating, the HB101 superdonor was conjugated with strain KD. Pseudomonas cells with integrated plasmid were selected for based on resistance to kanamycin $\left(25 \mu \mathrm{g} \mathrm{ml}^{-1}\right)$ and chloramphenicol $\left(40 \mu \mathrm{g} \mathrm{ml}^{-1}\right)$. Excision of the vector by a second homologous recombination event was sought by enrichment for tetracycline-sensitive cells using carbenicillin at $6 \mu \mathrm{g} \mathrm{ml}^{-1}$ (Reimmann et al. 1988). Selection for kanamycin resistance ensured the presence of the $\Omega$ cassette.

Correct insertion of the $\Omega$ cassette was verified by Southern blotting of PstI-digested genomic DNA of both the wild type and mutant using a digoxigenin-labeled $h r c V$ probe derived from Erwinia amylovora CNPB136 (Stuber et al. 2003), and by PCR using primers $\Omega$-fw (5'-AGTTCACCACTAGGCGA TTG-3') and $\Omega$-rev (5'-GTCATACAACACGGCATGAC-3'), 
which anneal to the flanking regions of the $\Omega$ cassette insertion site in $h r c V$. PCR amplification was carried out in $20-\mu l$ reaction mixtures containing $5 \mu \mathrm{l}$ of cell lysate, as described by Rezzonico and associates (2003). PCR included an initial denaturation of $5 \mathrm{~min}$ at $94^{\circ} \mathrm{C}$, followed by 30 cycles of $30 \mathrm{~s}$ at $94^{\circ} \mathrm{C}, 30 \mathrm{~s}$ at $57.5^{\circ} \mathrm{C}$, and $1 \mathrm{~min}$ at $72^{\circ} \mathrm{C}$, and then a final elongation of $10 \mathrm{~min}$ at $72^{\circ} \mathrm{C}$. The size of PCR products was checked by electrophoresis in $1.5 \%$ agarose.

Strain KD and the $h r c V$ mutant were compared based on carbon source utilization in Biolog GN microplates (Biolog Inc., Hayward, CA, U.S.A.) as described by the manufacturer. Growth rates in LB, King's B, potato dextrose broth, and minimal medium were determined using optical density measurements of the bacterial cultures at $600 \mathrm{~nm}$. The production of hydrogen cyanide was assessed qualitatively using HCN indicator paper, as described by Castric and Castric (1983), and pyoverdins were studied and compared by isoelectric focusing ( $20 \mathrm{~h}$ at $10 \mathrm{~W}, 3,500 \mathrm{~V}$ and $50 \mathrm{~mA}$ ) on Immobiline Dry Strips NL pH 3-10 (Amersham Pharmacia Biotech, Piscataway, NJ, U.S.A.) using a 2117 Miltipor II electrophoresis unit (LKB, Bromma, Sweden) as described by Meyer and associates (2002).

\section{Biocontrol experiments in vivo.}

Cucumber experiments were done as described (SharifiTehrani et al. 1998), except that plants were grown in nonsterile commercial potting mix (BF4 substratum; TrefDe-Baat, GVZ-Bolltec AG, Zürich, Switzerland). Briefly, $P$. ultimum was grown for 7 days on autoclaved millet seed (Biofarm, Kleindietwil, Switzerland). Seeds were chopped and the resulting particles, $1 \mathrm{~mm}$ in diameter, were used to infest potting mix at the rate of $1 \mathrm{~g}$ of particles per $2 \mathrm{~cm}^{3}$ of potting mix. In controls without added pathogen, the same amount of autoclaved millet was used. Seed (Wyss Samen und Pflanzen AG, Zuchwil, Switzerland) of cucumber (Cucumis sativa cv. Chinesische Schlange) were surface disinfected as described (Sharifi-Tehrani et al. 1998) and germinated for 3 days on $1.2 \%$ water agar at $24^{\circ} \mathrm{C}$ in the dark. Bacterial cells from overnight LB cultures of strain $\mathrm{KD}$ or its $h r c V^{-}$mutant were washed with $0.9 \% \mathrm{NaCl}$ solution, and the suspensions adjusted to an optical density at $600 \mathrm{~nm}\left(\mathrm{OD}_{600}\right)$ of 1.25 (i.e., $\left.10^{9} \mathrm{CFU} \mathrm{ml} \mathrm{m}^{-1}\right)$. Cell suspension $(100 \mathrm{ml})$ was added to the potting mix, corresponding to $5 \times 10^{7} \mathrm{CFU}$ added per gram of potting mix. In controls without bacterial inoculant, the same volume of autoclaved double-distilled water was added. After the inoculation or inoculations, the potting mix was mixed thoroughly. A total of 36 experimental pots $\left(70 \mathrm{~cm}^{3}\right.$, containing approximately $85 \mathrm{~g}$ of potting mix) distributed over nine trays (i.e., nine replicates, with four pots per replicate) were prepared per treatment. Five pregerminated cucumber seeds were sown in each pot. The trays were placed in a growth chamber with $16 \mathrm{~h}$ of light $(15 \mathrm{kLux})$ at $22^{\circ} \mathrm{C}$ and $8 \mathrm{~h}$ of darkness at $17^{\circ} \mathrm{C}$ following a randomized block design. Double-distilled water was added to each tray (150 $\mathrm{ml}$ after sowing, then $50 \mathrm{ml}$ daily) to reach approximately $35 \% \mathrm{wt} / \mathrm{wt}$ in the potting mix by capillary movement of water.

At 7 days, emerging plants were counted and weighed, and cell numbers of the bacterial inoculants determined in triplicate for the potting mix substratum, the rhizosphere (i.e., the potting mix adhering closely to the root), and the root itself (i.e., the root surface and internal root tissues) as described (Hase et al. 2000). Plating was done onto potato dextrose agar (Beever and Bollard 1970) (prepared according to instructions from Difco Laboratories) containing chloramphenicol $\left(50 \mu \mathrm{g} \mathrm{ml}^{-1}\right)$, which enabled selection and visual identification of $\mathrm{KD}$ and its $h r c V^{-}$mutant, both producing blue colonies on this medium. Colonies were counted after $24 \mathrm{~h}$ of incubation at $27^{\circ} \mathrm{C}$. No blue colony was found when studying treatments without bacterial inoculation. Strain identity was verified by PCR using primers $\Omega$-fw and $\Omega$-rev described above.

\section{Construction of an $\mathbf{h r p J}$ '-inaZ transcriptional fusion in plasmid pAD1.}

Plasmid pAD1 was provided by N. Chaney and J. E. Loper (United States Department of Agriculture-Agricultural Research Service Horticultural Crops Research Unit, Corvallis, OR, U.S.A.). It had been constructed by replacing $g f p$ with inaZ in pPROBE' $g f p$ [tagless] (Miller et al. 2000) (accession number AF286456), as follows. The coding region of inaZ from Pseudomonas syringae S203 (accession number X03035) was excised from pJEL1696 (Loper and Lindow 1994) using $E c o$ RI and BamHI and gel purified. The coding region of the green fluorescent protein gene $g f p$ was excised from pPROBE'gfp[tagless] by HindIII deletion and the resulting vector digested with HindIII and BamHI, prior to the ligation of inaZ using a combination of EcoRI-XmnI and HindIII-XmnI adaptors, according to the manufacturer's instructions (New England Biolabs, Beverly, MA, U.S.A.). Plasmid pAD1 was transferred into Pseudomonas strain CHA0 by mobilization from $E$. coli DH5 $\alpha$ (Sambrook et al. 1989).

The 30-mer primers prottss-2fB (5'-GTCTGGATCCCCCT GATCTTTTGCGATGTG-3') and prottss-1rB (5'-TCTTGGAT CCGTCGAGCTGACGAAGGAGAG-3'), both containing a BamHI restriction site (underlined), were designed based on TTSS gene sequences of strain KD (Rezzonico et al. 2004) to amplify a 405-bp fragment containing the promoter region of the hrpJ-hrcN operon of KD in a PCR reaction consisting of an initial denaturation of $5 \mathrm{~min}$ at $95^{\circ} \mathrm{C}$, followed by $30 \mathrm{cy}-$ cles of $30 \mathrm{~s}$ at $94^{\circ} \mathrm{C}, 30 \mathrm{~s}$ at $60^{\circ} \mathrm{C}$, and $1 \mathrm{~min}$ at $72^{\circ} \mathrm{C}$, and a final elongation of $10 \mathrm{~min}$ at $72^{\circ} \mathrm{C}$. The size of the PCR product was checked by electrophoresis in $1.5 \%$ agarose and the fragment purified using QIAquick Gel Extraction Kit (QIAGEN, Hilden, Germany). Meanwhile, vector pAD1 was obtained from a 15-ml overnight culture of Pseudomonas strain $\mathrm{CHA} 0 / \mathrm{pAD} 1$ in LB containing kanamycin $\left(50 \mu \mathrm{g} \mathrm{ml}^{-1}\right)$ using the Wizard Plus SV Minipreps DNA Purification System (Promega Corp., Madison, WI, U.S.A.). Both PCR amplicon and plasmid vector were digested with BamHI and ligated together, after vector dephosphorylation using shrimp alkaline phosphatase (USB Corporation, Cleveland, $\mathrm{OH}$, U.S.A.), using T4-ligase (USB Corporation). The ligation product was transferred into competent $E$. coli $\mathrm{DH} 5 \alpha$ cells (Life Technologies Inc., Rockville, MD, U.S.A.) by transformation, following the manufacturer's instructions. The resulting colonies were screened for single copy and correct orientation of the insert in the plasmid using restriction enzymes EcoRI and ClaI, and PCR with primers AD1mcs-3f (5'-AGG AATTGGGGATCGGAAGC-3', annealing to the multiple cloning site of pAD1) and InaZ-2r (5'-ATGTCTGCAACGG CAACTTC-3', annealing to the beginning of the reporter gene), both designed in the current work, in combination with prottss-2fB and prottss- $1 \mathrm{rB}$ (Fig. 1). The plasmid in the colony thus selected was named pADJ6 (Fig. 1). The promoter region was verified by PCR using primers AD1mcs-3f and InaZ-2r and sequencing using the ABI PRISM BigDye Terminators Cycle Sequencing Kit (v3.0; Applied Biosystems, Foster City, CA, U.S.A.) and an ABI3100 Sequencer (Applied Biosystems), followed with analysis using the Chromas software (version 1.45; Technelysium Pty. Ltd., Helensvale, Australia). The plasmid pADJ6 was purified from $E$. coli as described above and transformed into $\mathrm{CaCl}_{2-}$ competent KD cells, as described (Cohen et al. 1972). 
Stability of plasmid pADJ6 in vitro was determined by replica plating onto King's B agar supplemented with kanamycin $\left(50 \mu \mathrm{g} \mathrm{ml}^{-1}\right)$. During 4 days, strain KD/pADJ6 was subcultured each $12 \mathrm{~h}$ in $\mathrm{LB}$ without antibiotics at $27^{\circ} \mathrm{C}$ with shaking. The number of generations was estimated and the percentage of kanamycin-resistant colonies (indicative of the presence of pADJ6) was determined. The basal ice nucleation activity of the inoculum was assessed in 10-fold dilutions of overnight LB cultures, as described below.

\section{Analysis of inaZ activity in vitro.}

The activity of the hrp promoter was assessed in vitro by measuring the ice nucleation activity of strain KD/pADJ6. $\mathrm{KD} / \mathrm{pADJ} 6$ was inoculated at an initial $\mathrm{OD}_{600}=0.0001$ (corresponding to $4.9 \log _{10}$ cells $\mathrm{ml}^{-1}$ ) in $30 \mathrm{ml}$ of LB medium, either alone or together with one 6-mm disk of malt agar overgrown with $P$. ultimum, $2 \mathrm{~g}$ of 2-day-old autoclaved cucumber seedlings, or $2 \mathrm{~g}$ of 2 -day-old seedlings that had been surface disinfected for $30 \mathrm{~min}$ in a $2 \%$ sodium hypochloride solution. Kanamycin $\left(10 \mu \mathrm{g} \mathrm{m} \mathrm{m}^{-1}\right)$ was added when using surface-disinfected cucumber, in order to avoid the growth of bacterial contaminants. One disk of uninoculated malt agar was added in the control. Samples were taken at 0, 8, $16,19,24$, and $27 \mathrm{~h}$ after inoculation. Bacterial growth was assessed by measuring the $\mathrm{OD}_{600}$ and cell numbers estimated (with $0.125 \mathrm{OD}_{600}$ units corresponding to $10^{8}$ cells $\mathrm{ml}^{-1}$ ). inaZ activity in each sample was determined using 10-fold serial dilutions, as described below.

\section{Analysis of inaZ activity in nonsterile potting mix.}

The set-up of the experiment to assess inaZ activity in potting mix was similar to that of the biocontrol experiment described above, and KD carrying the hrpJ'-inaZ plasmid pADJ6 was used (instead of strain KD and its $h r c V^{-}$mutant). Four pots containing five cucumber seeds each were used per treatment. After 7 days in the growth chamber, the plants from each pot were removed from the potting mix and pooled. The root systems of all emerging plants were sampled and CFU of the inoculant in potting mix substratum, rhizosphere, and roots were enumerated by plating on potato dextrose agar supplemented with kanamycin $\left(50 \mu \mathrm{g} \mathrm{ml}^{-1}\right)$, as described above. The same 10-fold serial dilutions also were subjected to the ice nucleation assay. This was done using a modification of the method described by Loper and Lindow (1997). For all samples, the concentration of ice nuclei was determined by placing 40 drops (each of a volume $\mathrm{V}^{\mathrm{dr}}=10 \mu \mathrm{l}$ ) on a wax-coated (Turtle Wax, Skelmersdale, England) aluminum foil sheet cooled to $-6^{\circ} \mathrm{C}$ in an ethanol bath. The fraction $(f)$ of droplets freezing in each dilution $\left(\mathrm{D}^{\mathrm{S}}\right.$ representing the dilution from the initial suspension) was recorded and ice nucleation activity was expressed as the number of nuclei produced. The number of nuclei was determined as $\ln (1 /[1-f]) /\left[\mathrm{V}^{\mathrm{dr}} \times \mathrm{D}^{\mathrm{S}}\right)$, as proposed by Vali (1971), and normalized for the number of CFU recovered from each sample.

\section{Pectinase activity of $P$. ultimum in vitro.}

The effect of strain KD and its $h r c V$ mutant on the activity of the pectinase polygalacturonase (EC 3.2.1.15) produced by $P$. ultimum was measured in Czapek medium supplemented $\left(5 \mathrm{~g} \mathrm{l}^{-1}\right)$ with malt (i.e., Czapek-Malt) or in LB, using Costar 12-well TPP Microplates (Corning Inc. Life Sciences, Acton, MA). One 6-mm plug of $P$. ultimum, washed bacterial cells, or both was added to $3 \mathrm{ml}$ of medium. In certain wells, $500 \mu \mathrm{l}$ of a suspension obtained by the maceration of autoclaved cucumber seedlings in $0.9 \% \mathrm{NaCl}$ also was added. Controls received a plug of either noninoculated malt agar, $500 \mu \mathrm{l}$ of $0.9 \% \mathrm{NaCl}$ solution, or both. The initial $\mathrm{OD}_{600}$ when bacteria were used was 0.125 (i.e., $10^{8}$ cells $\mathrm{ml}^{-1}$ ). The microplates were incubated on a rotary shaker at $45 \mathrm{rpm}$ and $24^{\circ} \mathrm{C}$. Samples $(200 \mu \mathrm{l})$ were taken from each well at each sampling until $64 \mathrm{~h}$ after inoculation. Pectinase activity was assessed in a cup-plate assay done using 1.2\% agar plates containing $1 \%$ polygalacturonic acid, $1 \%$ yeast extract, 2.2 $\mathrm{mM}$ EDTA, and $110 \mathrm{mM}$ natrium acetate (pH 5.5) (Chatterjee et al. 1995). Holes (6 $\mathrm{mm}$ deep) were punched in the agar using a sterile 6-mm-diameter cork borer and filled with the samples. The plates were incubated for 2 days at $24^{\circ} \mathrm{C}$ and treated by pouring $37 \%$ fuming $\mathrm{HCl}$ (Merck, Darmstadt, Germany), which results in a clearance zone where polygalacturonic acid has been hydrolyzed, over the surface. Cup-plate data were recorded $30 \mathrm{~min}$ later and expressed as the ratio of the diameter of the clearing zone obtained with the sample supernatant divided by the diameter obtained with a solution containing 0.1 units of commercial pectinase (Sigma-Aldrich Chemie GmbH, Steinheim, Germany). No pectinase activity was found when adding bacteria or macerated cucumber seedlings in the absence of $P$. ultimum. Each treatment was studied in triplicate (i.e., in three wells, each located in a different microplate). The experiment was run twice, with similar results.

\section{Statistical analysis.}

All experiments were done two to three times, with similar results, and data from one trial are presented in the figures. In all experiments, each treatment was replicated at least three times. Data were subjected to analysis of variance and, when comparing three treatments or more, the means were separated (when appropriate) using Tukey's honestly significant difference tests. All analyses were done at $P<0.05$ using Systat (version 10.0; Systat Inc., Evanston, IL, U.S.A.).

\section{ACKNOWLEDGMENTS}

This work was supported by the Swiss National Foundation for Scientific Research (project 31-64048.00), the French Embassy in Switzerland (France-Switzerland research grant), and the France-Switzerland PAI project 'Germaine de Staël'. We thank N. Chaney and J. Loper (United States Department of Agriculture-Agricultural Research Service Horticultural Crops Research Unit, Corvallis) for the gift of plasmid pAD1, R. Notz (ETH) for technical advice in the ice nucleation experiments, and T. Corberand and P. Lemanceau (INRA, Dijon, France) for help with hypersensitive response assessment of strain KD.

\section{LITERATURE CITED}

Agrios, G. N. 1997. Plant Pathology, 4th ed. Academic Press, San Diego, CA, U.S.A.

Aldon, D., Brito, B., Boucher, C., and Genin, S. 2000. A bacterial sensor of plant cell contact controls the transcriptional induction of Ralstonia solanacearum pathogenicity genes. EMBO (Eur. Mol. Biol. Organ.) J. 19:2304-2314.

Alfano, J. R., Charkowski, A. O., Deng, W. L., Badel J. L., PetnickiOcwieja, T., van Dijk, K., and Collmer, A. 2000. The Pseudomonas syringae Hrp pathogenicity island has a tripartite mosaic structure composed of a cluster of type III secretion genes bounded by exchangeable effector and conserved effector loci that contribute to parasitic fitness and pathogenicity in plants. Proc. Natl. Acad. Sci. U.S.A. 97:48564861 .

Alfano, J., and Collmer, A. 1997. The type III (Hrp) secretion pathway of plant pathogenic bacteria: Trafficking harpins, Avr proteins, and death. J. Bacteriol. 179:5655-5662.

Anzai, Y., Kim, H., Park, J.-Y., Wakabayashi, H., and Oyaizu, H. 2000. Phylogenetic affiliation of the pseudomonads based on 16S rRNA sequence. Int. J. Syst. Evol. Microbiol. 50:1563-1589.

Beever, R. E., and Bollard, E. G. 1970. The nature of the stimulation of fungal growth by potato extract. J. Gen. Microbiol. 60:273-279.

Blanc-Potard, A.-B., and Lafay, B. 2003. MgtC as a horizontally-acquired virulence factor of intracellular bacterial pathogens: Evidence from molecular phylogeny and comparative genomics. J. Mol. Evol. 57:479-486. 
Bogdanove, A. J., Kim, J. F., Wei, Z.-M., Kolchinsky, P., Charkowski, A O., Conlin, A. K., Collmer, A., and Beer, S. V. 1998. Homology and functional similarity of an $h r p$-linked pathogenicity locus, $d s p E F$, of Erwinia amylovora and the avirulence locus avrE of Pseudomonas syringae pathovar tomato. Proc. Natl. Acad. Sci. U.S.A. 95:13251330 .

Campbell, N. A., Reece, J. B., and Mitchell, L. G. 1999. Biology, 5th ed Addison Wesley Longman Inc., New York.

Casper-Lindley, C., Dahlbeck, D., Clark, E. T., and Staskawicz, B. J. 2002. Direct biochemical evidence for type III secretion-dependent translocation of the AvrBs2 effector protein into plant cells Proc. Natl. Acad. Sci. U.S.A. 99:8336-8341.

Castric, K. F., and Castric, P. A. 1983. Method for rapid detection of cyanogenic bacteria. Appl. Environ. Microbiol. 61:3002-3007.

Cavalier-Smith, T. 1997. Sagenista and Bigyra, two phyla of heterotrophic heterokont chromists. Arch. Protistenkd. 148:253-267.

Cavalier-Smith, T., Allsopp, M. T. E. P., and Chao, E. E. 1994. Thraustochytrids are chromists, not Fungi: 18S rRNA signatures of Heterokonta. Phil. Trans. Royal Soc. Lond. (Ser. B) 346:387-397.

Chatterjee, A., Cui, Y., Liu, Y., Dumenyo, C. K., and Chatterjee, A. K 1995. Inactivation of rsmA leads to overproduction of extracellular pectinases, cellulases, and proteases in Erwinia carotovora subsp. carotovora in the absence of the starvation/cell density-sensing signal, $\mathrm{N}$-(3oxohexanoyl)-L-homoserine lactone. Appl. Environ. Microbiol. 61:1959-1967.

Cohen, S. N., Chang, A. C. Y., and Hsu, L. 1972. Nonchromosomal antibiotic resistance in bacteria: Genetic transformation of Escherichia coli by R-factor DNA. Proc. Natl. Acad. Sci. U.S.A. 69:2110-2114.

Dale, C., Plague, G. R., Wang, B., Ochman, H., and Moran, N. A. 2002. Type III secretion systems and the evolution of mutualistic endosymbiosis. Proc. Natl. Acad. Sci. U.S.A. 99:12397-12402.

Dale, C., Young, S. A., Haydon, D. T., and Welburn, S. C. 2001. The insect endosymbiont Sodalis glossinidius utilizes a type III secretion system for cell invasion. Proc. Natl. Acad. Sci. U.S.A. 98:1883-1888.

Ellis, R. J., Timms-Wilson, T. M., and Bailey, M. J. 2000. Identification of conserved traits in fluorescent pseudomonads with antifungal activity. Environ. Microbiol. 2:274-284.

Fellay, R., Frey, J., and Krisch, H. 1987. Interposon mutagenesis of soil and water bacteria: A family of DNA fragments designed for in vitro insertional mutagenesis of gram-negative bacteria. Gene 52:147-154.

Fouts, D. E., Abramovitch, R. B., Alfano, J. R., Baldo, A. M., Buell, C. R., Cartinhour, S., Chatterjee, A. K., D’Ascenzo, M., Gwinn, M. L., Lazarowitz, S. G., Lin, N. C., Martin, G. B., Rehm, A. H., Schneider, D. J., van Dijk, K., Tang, X., and Collmer, A. 2002. Genomewide identification of Pseudomonas syringae pv. tomato DC3000 promoters controlled by the HrpL alternative sigma factor. Proc. Natl. Acad. Sci. U.S.A. 99:2275-2280.

Fouts, D. E., Badel, J. L., Ramos, A. R., Rapp, R. A., and Collmer, A 2003. A Pseudomonas syringae pv. tomato DC3000 Hrp (Type III secretion) deletion mutant expressing the Hrp system of bean pathogen $P$. syringae pv. syringae 61 retains normal host specificity for tomato. Mol. Plant-Microbe Interact. 16:43-52.

Freiberg, C., Fellay, R., Bairoch, A., Broughton, W. J., Rosenthal, A., and Perret, X. 1997. Molecular basis of symbiosis between Rhizobium and legumes. Nature 387:394-491.

Gottfert, M., Rothlisberger, S., Kundig, C., Beck, C., Marty, R., and Hennecke, H. 2001. Potential symbiosis-specific genes uncovered by sequencing a 410-kilobase DNA region of the Bradyrhizobium japonicum chromosome. Mol. Microbiol. 183:1405-1412.

Hase, C., Hottinger, M., Moënne-Loccoz, Y., and Défago, G. 2000. Survival and cell culturability of biocontrol Pseudomonas fluorescens CHA0 in the rhizosphere of cucumber grown in two soils of contrasting fertility status. Biol. Fertil. Soils 32:217-221.

Holeva, M. C., Bell, K. S., Hyman, L. J., Avrova, A. O., Whisson, S. C., Birch, P. R. J., and Toth, I. K. 2004. Use of a pooled transposon mutation grid to demonstrate roles in disease development for Erwinia carotovora subsp. atroseptica putative type III secreted effector (DspE/A) and helper (HrpN) proteins. Mol. Plant-Microbe Interact. 17:943-950.

Hueck, C. J. 1998. Type III protein secretion systems in bacterial pathogens of animals and plants. Microbiol. Mol. Biol. Rev. 62:379-433.

Huynh, T. V., Dahlbeck, D., and Staskawicz, B. J. 1989. Bacterial blight of soybean: Regulation of a pathogen gene determining host cultivar specificity. Science 245:1374-1377.

King, E. O., Ward, M. K., and Raney, D. E. 1954. Two simple media for the demonstration of pyocyanin and fluorescein. J. Lab. Clin. Med. 44:301-307.

Loper, J. E., and Lindow, S. E. 1994. A biological sensor for iron available to bacteria in their habitats on plant surfaces. Appl. Environ. Microbiol. 60:1934-1941.
Loper, J. E., and Lindow, S. E. 1997. Reporter gene systems useful in evaluating in situ gene expression by soil- and plant-associated bacteria. Pages 482-492 in: Manual of Environmental Microbiology. C. J. Hurst, G. R. Knudsen, M. J. McInerney, L. D. Stetzenbach, and M. V. Walter, eds. ASM Press, Washington, DC.

Manulis, S., and Barash, I. 2003. Pantoea agglomerans pvs. gypsophilae and betae, recently evolved pathogens? Mol. Plant Pathol. 4:307-314.

Mazurier, S., Lemunier, M., Siblot, S., Mougel, C., and Lemanceau, P. 2004. Distribution and diversity of type III secretion system-like genes in saprophytic and phytopathogenic fluorescent pseudomonads. FEMS (Fed. Eur. Microbiol. Soc.) Microb. Ecol. 49:455-467.

Meinhardt, L. W., Krishnan, H. B., Balatti, P. A., and Pueppke, S. G. 1993. Molecular cloning and characterization of a Sym plasmid locus that regulates cultivar-specific nodulation of soybean by Rhizobium fredi USDA257. Mol. Microbiol. 9:17-29.

Meyer, J. M., Geoffroy, V. A., Baida N., Gardan, L., Izard, D., Lemanceau, P., Achouak, W., and Palleroni, N. J. 2002. Siderophore typing, a powerful tool for the identification of fluorescent and nonfluorescent pseudomonads. Appl. Environ. Microbiol. 68:2745-2753.

Miller, W. G., Leveau, J. H., and Lindow, S. E. 2000. Improved $g f p$ and inaZ broad-host-range promoter-probe vectors. Mol. Plant-Microbe Interact. 13:1243-1250.

Mulya, K., Takikawa, Y., and Tsuyumu, S. 1996. The presence of regions homologous to hrp cluster in Pseudomonas fluorescens PfG32R. Ann. Phytopathol. Soc. Jpn. 62:355-359.

Ochman, H., and Moran, N. A. 2001. Genes lost and genes found: Evolution of bacterial pathogenesis and symbiosis. Science 292:1096-1098.

Prentki, P., and Krisch, H. M. 1984. In vitro insertional mutagenesis with a selectable DNA fragment. Gene 29:303-313.

Preston, G. M., Bertrand, N., and Rainey, P. B. 2001. Type III secretion in plant growth-promoting Pseudomonas fluorescens SBW25. Mol. Microbiol. 41:999-1014.

Rainey, P. 1999. Adaptation of Pseudomonas fluorescens to the plant rhizosphere. Environ. Microbiol. 1:243-257.

Ramette, A., Frapolli, M., Défago, G., and Moënne-Loccoz, Y. 2003. Phylogeny of HCN synthase-encoding hcnBC genes in biocontrol fluorescent pseudomonads and its relationship with host plant species and HCN synthesis ability. Mol. Plant-Microbe Interact. 16:525-535.

Reimmann, C., Rella, M., and Haas, D. 1988. Integration of replication defective R68.45-like plasmids into the Pseudomonas aeruginosa chromosome. J. Gen. Microbiol. 134:1515-1523.

Rezzonico, F., Défago, G., and Moënne-Loccoz, Y. 2004. Comparison of ATPase-encoding type III secretion system $h r c N$ genes in biocontrol fluorescent pseudomonads and in phytopathogenic proteobacteria. Appl. Environ. Microbiol. 70:5119-5131.

Rezzonico, F., Moënne-Loccoz, Y., and Défago, G. 2003. Effect of stress on the ability of a phlA-based quantitative competitive PCR assay to monitor biocontrol strain Pseudomonas fluorescens CHA0. Appl. Environ. Microbiol. 69:686-690.

Rosqvist, R., Magnusson, K.-E., and Wolf-Watz, H. 1994. Target cell contact triggers expression and polarized transfer of Yersinia YopE cytotoxin into mammalian cells. EMBO (Eur. Mol. Biol. Organ.) J. 13:964-972.

Sambrook, J., Fritsch, E. F., and Maniatis, T. 1989. Molecular Cloning: A Laboratory Manual, 2nd ed. Cold Spring Harbor Laboratory Press, Cold Spring Harbor, NY.

Sharifi-Tehrani, A., Zala, M., Natsch, A., Moënne-Loccoz, Y., and Défago, G. 1998. Biocontrol of soil-borne fungal plant diseases by 2,4-diacetylphloroglucinol-producing fluorescent pseudomonads with different restriction profiles of amplified $16 \mathrm{~S}$ rDNA. Eur. J. Plant Pathol. 104:631-643.

Stuber, K., Frey, J., Burnens, A. P., and Kuhnert, P. 2003. Detection of type III secretion genes as a general indicator of bacterial virulence. Mol. Cell. Probes 17:25-32.

Sullivan, J. T., Patrick, H. N., Lowther, W. L., Scott, D. B., and Ronson, C W. 1995. Nodulating strains of Rhizobium loti arise through chromosomal symbiotic gene transfer in the environment. Proc. Natl. Acad. Sci. U.S.A. 69:8985-8989.

Vali, G. 1971. Quantitative evaluation of experimental results on heterogeneous freezing nucleation of supercooled liquids. J. Atmos. Sci. 28:402 409.

Valverde, C., Heeb, S., Keel, C., and Haas, D. 2003. RsmY, a small regulatory RNA, is required in concert with RsmZ for GacA-dependent expression of biocontrol traits in Pseudomonas fluorescens CHA0. Mol. Microbiol. 50:1361-1379.

Vieira, J., and Messing, J. 1991. New pUC-derived cloning vectors with different selectable markers and DNA replication origins. Gene 100:189-194

Voisard, C., Bull, C. T., Keel, C., Laville, J., Maurhofer, M., Schnider, U., Défago, G., and Haas, D. 1994. Biocontrol of root diseases by Pseudomonas fluorescens $\mathrm{CHA0:}$ Current concepts and experimental approaches. 
Pages 67-89 in: Molecular Ecology of Rhizosphere Microorganisms. F. O'Gara, D. Dowling, and B. Boesten, eds. VCH Publishers, Weinheim, Germany.

Walton, J. D. 1994. Deconstructing the cell wall. Plant Physiol. 104:11131118.

Watarai, M., Tobe, T., Yoshikawa, M., and Sasakawa, C. 1995. Contact of Shigella with host cells triggers release of Ipa invasins and is an essential function of invasiveness. EMBO (Eur. Mol. Biol. Organ.) J. 14:24612470.

Xiao, Y., and Hutcheson, S.W. 1994. A single promoter sequence recog- nized by a newly identified alternate sigma factor directs expression of pathogenicity and host range determinants in Pseudomonas syringae. J. Bacteriol. 176:3089-3091.

\section{AUTHOR-RECOMMENDED INTERNET RESOURCES}

CABI database IndexFungorum: www.indexfungorum.org/ Technelysium Chromas software version 1.45: www.technelysium.com.au/chromas.html 